\title{
The Influence of Customer Satisfaction and Service Quality on Grand Royal Ceramic Purchase Decisions at Pt. Era Graha Perkasa Medan
}

\author{
Michael Pranata, Wilson Cong, Oscar Wijaya, Venny*, Lenti Dayan \\ Faculty of Economics, Universitas Prima Indonesia, Indonesia
}

\begin{abstract}
Each company aims to achieve organizational goals by earning maximum sales. Sales are very important for a company because it can determine whether the company development is good or not. High customer satisfaction will increase purchase decisions, so is the quality of service.

Starting from the brief description above, so the following problems are formulated by considering customer satisfaction and service quality for the purchase decisions of Grand Royal ceramics at PT Era Graha Perkasa Medan. The data was collected through interviews, questionnaires, and documentation studies. The data was then analyzed using multiple regression. The population of this study was all customers at PT Era Graha Perkasa Medan totaling 136 persons. The sample is determined by using Slovin formula which resulted in 101 persons. The research results indicate that customer satisfaction and service quality has an influence of purchase decisions because the $F_{\text {count }}$ value $>F_{\text {table }}(10.158>3.09)$ with Sig. $0,000<0,05$. Partial is very significant for purchase decisions because customer satisfaction variable has a calculated value of 2.389 and $t_{\text {table }}$ value of 1.984, then the value of $t_{\text {count }}>t_{\text {table }}(2.389>1.984)$ with a significant value of $0.019<0.05$ and ttable values of 1.984 , then the value of tcount $>$ ttable $(2.885>1.984)$ with a significant value of $0.005<0.05$, so the quality of service is the most dominant factor affecting the choice of satisfaction spending at PT Era Graha Perkasa Medan. This research concludes that simultaneous and partial customer satisfaction and service quality is very important to the purchase decision of Grand Royal ceramics at PT Era Graha Perkasa Medan.
\end{abstract}

Keywords : Customer Satisfaction, Service Quality, Purchasing Decisions.

DOI: $10.7176 /$ RHSS/9-2-08

\section{INTRODUCTION}

During the current modernization period, it seems that every company is trying to improve its quality and competitiveness. The most important thing that a company usually improves is sales. Sales play an important role for each company because it can cover all company's operational costs. In addition, the company can develop its company with profits made from sales. Company sales can be improved by paying attention to purchasing decisions. Purchase decisions can be made by consumers when making a decision to buy a product. Purchase decisions can be influenced by several factors such as customer satisfaction and service quality.

Customer satisfaction is very important for a company to keep maintaining because the higher the customer satisfaction, the more lavish the customer to buy the company's product. Therefore, customer satisfaction must be maintained so that the customers remain lavish and buy products from the company. As with the quality of service. The better the quality of service, the more interested the customer to buy products from the company because service is something that customers will always remember when buying a product.

PT Era Graha Perkasa Medan is one of the companies engaged in Grand Royal ceramics sales in Medan.

PT Era Graha Perkasa Meda was thought to have a problem with the purchasing decision.

The company is not able to reach the sales target set by the company which indicates a problem with the purchase decision. The highest sales of the company were in May 2017, which was $71.78 \%$ caused the thinning of the stock, whilst the lowest sales were in January 2017, which was $50.93 \%$ caused by the customers having made purchases in the previous month to prepare for the new year.

Problems with purchase decisions are thought to be influenced by customer satisfaction. There are still many complaints from customers because of their dissatisfaction with the company which makes them stop buying there. Most customers to stop buying was in March 2017 and October 2017. The most reason is that customers find suppliers selling at lower prices.

The number of customer complaints causes less interest in customers to buy there again. The highest number of complaints was in April, which was 12 complaints with the most problems were the delays in customer orders.

Based on the phenomenon of problems that occur in the company, the researchers conducted a study at this company entitled "The Influence of Customer Satisfaction and Service Quality on Grand Royal Ceramics Purchase Decision at PT Era Graha Perkasa Medan." 


\section{Problems Identification}

Based on the background described above, the problems identification of in this study are:

1. Customer satisfaction is still low so that they decide to stop subscribing.

2. Service quality experiences a problem so it is not able to attract consumers interest to at the company again.

3. Purchase decisions are disrupted so that the sales at the company do not reach the target.

\section{Problem Formulation}

Based on the background and identification of the problems described above, problem formulation can be made, namely:

1. How is the influence of customer satisfaction on the purchase decision of Grand Royal ceramic at PT Era Graha Perkasa Medan?

2. How is the influence of service quality on the purchase decisions of Grand Royal ceramics at PT Era Graha Perkasa Medan?

3. How is the influence of customer satisfaction and service quality on the purchase decision of Grand Royal ceramics at PT Era Graha Perkasa Medan?

\section{Research Goal}

The purpose of this study is to:

1. Test and analyze the effect of customer satisfaction on the purchase decision of Grand Royal ceramics at PT Era Graha Perkasa Medan.

2. Test and analyze the effect of service quality on the purchase decision of Grand Royal ceramic at PT Era Graha Perkasa Medan.

3. Test and analyze the effect on service satisfaction and service quality on the Grand Royal ceramics purchase decision at PT Era Graha Perkasa Medan.

\section{Research Benefits}

The benefits of this research are:

1. For Researchers

As a basis for increasing the knowledge of researchers regarding the effect of customer satisfaction and service quality on purchase decisions.

2. For Further Research

As a reference for future researchers who will observe the same problems or similar ones.

3. For PT Era Graha Perkasa Medan

As a basis for increasing purchase decisions in the future by improving customer satisfaction and service quality.

4. For UNPRI

The results of this study are expected to be a material for library research, learning and enriching scientific research at Universitas Prima Indonesia

Faculty of Economics, Especially Management Department.

\section{Satisfaction Theoretical Basis}

According to Abdullah and Tantri (2015: 38), "Satisfaction is the level of someone's feelings after comparing product performance (or result) that she/he feels and his/her expectations."

According to Suparyanto and Rosad (2015: 5), "Satisfaction is the level of how much a customer's needs and desires are met by the product consumed."

According to Arianty et al. (2015: 21), "Customer satisfaction is the feeling of the consumer after feeling between what he has received and the expectations he wants."

According to Herlambang (2014: 79), To achieve customer satisfaction, in the context of service, several conditions and businesses are needed, among others:

1. An understanding of the philosophy of customer satisfaction

2. Getting to know customer needs or expectations

3. Making standards and measuring customer satisfaction

4. Employee orientation in service

5. Training

6. Employees' involvement

7. Recognition and appreciation

According to Hasan (2014: 102-105), the benefits of customer satisfaction are:

1. Income 
Customers truly satisfied contribute 2.6 times to the income compared to customers who are somewhat satisfied.

2. Reactions to low-cost producers.

Competition with the price war - cutting prices is considered a powerful weapon by many companies to gain market share. There are many facts about customers who are willing to pay a higher price for better service and quality products.

3. Economic benefits.

Various studies show that sustaining and satisfying

customers are far easier than constantly attracting or prospecting new customers, the cost of maintaining customers is four to six times cheaper than the cost of finding new customers.

4. Price sensitivity reduction.

Customers who are satisfied with a company tend to bid less frequently. In this case, customer satisfaction shifts focus to service prices and quality.

5. The key of to achieve success

Customer satisfaction is an indicator of success that measures the tendency of customer reactions to the company.

6. Word-of-mouth relationship, satisfied customers are able to:

a. Make the relationship between companies and their customers harmonious.

b. Provide a good basis for repurchasing and creating customer loyalty.

c. Become an advocate for the company, especially if a company's reputation is harassed by others.

d. Find a positive recommendation by word of mouth that is very profitable for the company. According to Supranto and Limakrisna (2011: 243), "The purpose of customer satisfaction is to produce consumers who are committed or loyal to the brand."

According to Hasan (2014: 106-107), the methods that can be used to measure customer satisfaction are:

1. System of complaints and suggestions.

Violation-oriented organizations provide opportunities for customers to submit suggestions directly.

2. Ghost shopping.

This method is effective if company managers are willing to be ghost shoppers \& to directly know how their employees interact and treat customers.

3. Lost customer analysis.

Companies contact customers who have stopped buying or switching suppliers, in order to understand why stopping or moving suppliers.

4. Customer satisfaction survey

Independent research institutes conduct a study by using the customer satisfaction survey method.

\section{Service Quality}

According to Tjiptono and Chandra (2012:74), "Service quality reflects all dimensions of product offerings that produce benefits for customers."

According to Sangadji and Sopiah (2013: 99), "Service quality is a dynamic condition that relates to products, services, people, processes and environments that meet or exceed expectations."

Based on Abdullah and Tantri (2014: 44), "Service quality is the overall characteristics of an item or service that influences its ability to satisfy the expressed or implied needs

According to Tjiptono (2014: 107), factors that influence service quality are :

1. Information, product delivery schedules, prices, sales/service requirements, notifications of changes, receipts.

2. Consultations, such as advice provision, auditing, personal counseling, and management/technical consulting.

3. Order taking includes applications (membership in certain clubs or programs); order entry, and reservations (seating, tables, rooms, professional appointments, and admissions for limited facilities such as exhibitions).

4. Hospitality, transportation

5. Caretaking, attention and protection

6. Exceptions, special requests before product delivery, handle complaints/praise/suggestions, solving problems (guarantees for product usage failures; difficulties that arise in product usage; difficulties caused by product failure, including problems with other staff or customers); and restitution (money withdrawal, compensation, etc.).

7. Billing, invoice for individual transactions.

8. Payment, automatic reduction of customer's account. 
According to Suchaeri (2012: 7-8), The benefits of service quality are:

1. Creating customer loyalty and increasing the market and repeat sales

2. Increasing sales and profits

3. More sales, repeat business, bigger sales; increase in orders, and repeat orders.

4. More number of customers and the creation of new customers

5. Savings in marketing, advertising and promotion budgets

6. Having fewer customer complaints

7. Having a positive corporate reputation

8. Having been created the company development

9. Having been developed the employee productivity and morals because customers give positive responses to them

10. Employee relations will increase.

11. Suffering, absenteeism and employee delays are less

12. Less employee turnover

According to Soedjas (2014: 60), "The ultimate goal of service quality is to make customers loyal then repeat actions, not just actions."

Based on Sangadji and Sopiah (2013:100-101), the quality of dimensions are:

1. Reliability

That is the ability to accurately provide the promised services and to be trusted (dependently), especially in providing on-time services, guiding to the promised schedule, and without making mistakes;

2. Responsiveness

That is the willingness or desire of employees to help to provide services needed by consumers;

3. Assurance

Includes knowledge, abilities, friendliness, politeness, and trustworthiness from personal contacts to eliminate the nature of consumer doubt and make them feel free from danger and risk;

4. Empathy

It includes personal or company contact attitudes to understand needs and difficulties, consumers, good communication, personal attention, and ease of communication or relationships;

5. Physical products (Tangible)

The availability of physical facilities, equipment, and means of communication, and others can and must be in the service process.

\section{Purchase Decision}

According to Sangadji and Sopiah (2013: 121), purchase decisions are a process of integration that combines knowledge to evaluate two alternative behaviors or more and has one of them.

According to Sunyoto (2015: 3), purchase decisions are behavior shown by people in terms of planning, buying and using economic goods and services.

Based on Herlambang (2014: 62), purchase decisions are actions that are directly involved in acquiring, consuming, and spending products and services, including decisions to overtake and carry out these actions.

According to Arianty et al. (2015: 56), factors that influence purchase decisions are:

1. The appearance of needs and wants

If consumers' needs and desires are high so are the assessment and expectations and vice versa.

2. Past Experience

The experience of using the same product or other product has the same function.

3. Experience from a Friend

The quality of the product can also be obtained from the experience of friends who have used the product previously.

4. Advertising Communication

Advertising can change consumer expectations of an item. The advertisements presented and designed by the company will influence consumer expectations for a product.

According to Sangadji and Sopiah (2013: 10), there are several goals in determining purchase decisions, namely:

1. To implement the marketing concept as a plan to influence consumers

2. To understand the complex effects when consumers consume the products they buy.

3. To increase the confidence of managers (marketing) to predict consumer response after a marketing strategy is established and implemented.

4. Self-reference criterion Every consumer has a different level of understanding about the product she/he buys, those with either high or low understanding. 
According to Arianty et al. (2015: 54), the benefits of the company always follow consumer behavior, the company automatically always produces products with the latest innovations continuously.

According to Sunyoto (2014: 283), each purchase decision has seven structures. Those components are:

1. Decisions about the type of product.

Consumers can make decisions to buy a product. In this case the company must focus its attention on people who are interested in buying products and other alternatives they are considering.

2. Decisions about product form.

This decision also concerns the size, sound quality, style and so on. In this case, the company has to conduct marketing research to find out the preferences of consumers about the product in order to maximize the attractiveness of the brand.

3. Decision of brand

Consumers must make decisions about which brand will be purchased Every brand has its own differences. In this case, the company has to know how consumers choose a brand.

4. Decision about the seller.

Consumers must make a decision where the product will be purchased. In this case, producers, wholesalers, and retailers must know how consumers choose certain sellers.

5. Decision about total product

Consumers can make decisions about how many products to buy at a time. In this case, the company must prepare the number of products according to the different desires of the buyer.

6. Decision about the time of purchase.

Consumers can make decisions about how many products to buy at a time. In this case, the company must prepare the number of products according to the different desires of the buyers

7. Decision on how to pay

Consumers must make decisions about the payment method for the product purchased, whether in cash or in installments. The decision will influence the decision about the seller and the amount of the purchase. In this case, the company has to know the desire of the payment

\section{The Influence of Customer Satisfaction on the Purchase Decisions Theory}

According to Abdullah and Tantri (2015: 223), Consumers set a value expectation and act on the expectation of that value. Then, they will find out whether an offer really fulfills their expectation or not, which affects their satisfaction and the possibility to buy again.

According to Sunyoto (2015: 115), everyone makes a purchase with certain expectations about what the product or service will do when used, and satisfaction is the expected result.

According to Arianty et al. (2014: 21), customers who are satisfied with the products and services offered usually have the desire to repurchase the product and re-use the service when they need it.

\section{The Influence of Service Quality on Purchase Decision Thoery}

According to Suchaeri (2012: 5), "Customers will feel satisfaction and pleasure because of the quality of services provided. They will return to visit and buy."

According to Nitisusastro (2013: 203), "Regular and fair service will be very pleasing to consumers. Service product selling companies need to run various policies that aim to simplify the entire process which is part of the product and chart of product quality. Every company will carry out various efforts and continuous improvement so that consumers do buying activities.

Consumers will be more motivated to buy because the process is easy, cheap, and more enjoyable."

According to Abdullah and Tantri (2014: 44), "Today's customers are flooded with many choices of goods and services that they can buy. Customers determine service quality and value. 


\section{Conceptual Framework}

Based on the pre-existing description, a conceptual framework can be presented in Figure 1.
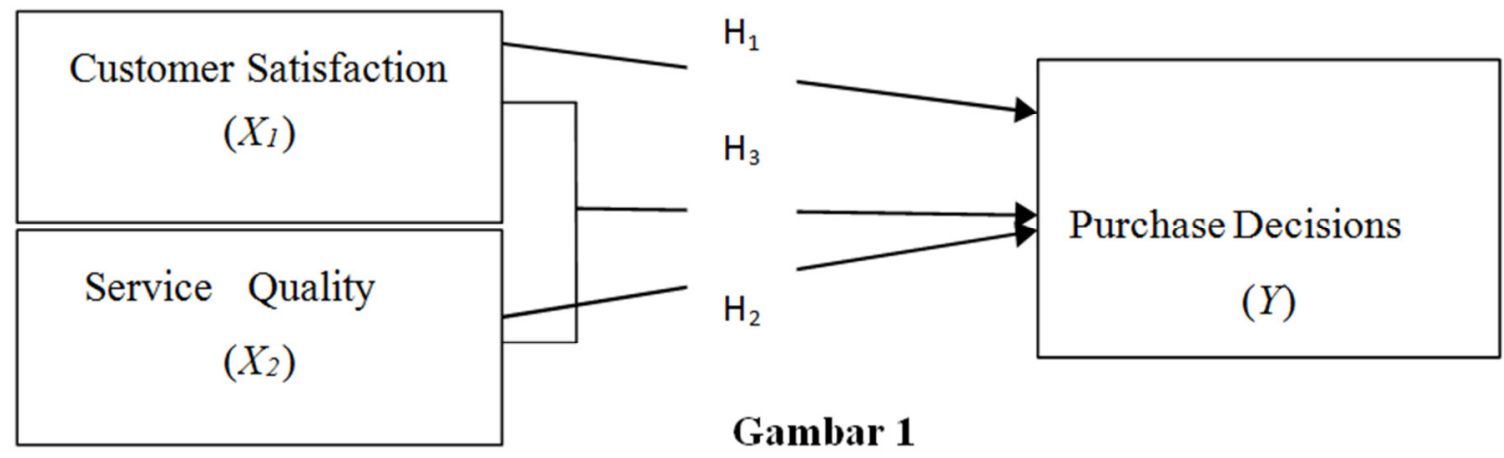

Gambar 1

\section{Conceptual Framework}

A hypothesis is a temporary answer to the research problem until proven through the collected data. The hypothesis of this research is:

1. $\mathrm{H}_{1}$ : Customer satisfaction affects the purchase decisions of Grand Royal ceramics at PT Era Graha Perkasa Medan.

2. Service quality affects the purchase decisions of Grand Royal ceramics at PT Era Graha Perkasa Medan.

3. Customer satisfaction and service quality affect the purchase decisions of Grand Royal ceramics at PT Era Graha Perkasa Medan.

\section{METHODOLOGY}

The study was conducted at PT Era Graha Perkasa Medan, located on Jalan Medan. PT Era Graha Perkasa Medan is a company engaged in the sale sector of Grand Royal ceramics in Medan. The study was conducted in October 2017 until February 2018.

The research approach used is a quantitative approach because this research has a clear and regular flow. This type of research is a quantitative descriptive study. This was an explanantory research.

The population of this study was all customers at PT Era Graha Perkasa Medanyang totaling 136 respondents. For that reason, the samples of this study were 101 customers, while the remaining 30 customers were for testing validity and reliability.

Before the obtained regression used to test the hypothesis, the model was tested first for classical assumptions. Classic assumption tests carried out include normality test, heteroscedasticity test, and multicollinearity test. This data analysis model uses multiple regression analysis.

\section{RESULTS AND DISCUSSION}

Multiple regression analysis is used to predict changes (ups and downs) of the dependent variable explained/linked by two or more independent variables as manipulated predictor factors and to determine whether there is or not influence between the independent variables on the dependent variable.

Table 1

The Result of Multople Regression Analysis

\begin{tabular}{|rl|r|r|r|r|r|}
\hline \multirow{2}{*}{ Model } & \multicolumn{2}{|c|}{ Unstandardized Coefficients } & Standardized Coefficients & \multirow{2}{*}{ Sig. } \\
\cline { 3 - 5 } & \multicolumn{1}{|c|}{ B } & Std. Error & Beta & & \\
\hline \multirow{2}{*}{1} & (Constant) & 12.130 .243 & 3.195 .102 & .230 & 2.389 & .000 \\
& Customer_Satisfaction & & & .019 \\
& Service_Quality & .297 & .103 & .278 & 2.885 & .005 \\
\hline
\end{tabular}

a. Dependent Variable : Purchase_Decisions

$$
\mathrm{Y}=12.130+0.243 \mathrm{X}_{1}+\mathbf{0 . 2 9 7} \mathrm{X}_{2}
$$

Based on these equations, it can be described as follows:

a. The constant value (a) is 12,130 meaning that if there is no variable of customer satisfaction and service quality, then the value of the purchase decision is 12,130 units.

b. Customer satisfaction variable $\left(\mathrm{X}_{1}\right)$ is $\mathrm{b}_{1}=0.243$ and has a positive value meaning that every increase in customer satisfaction variable by 1 unit, so the purchase decision value will increase by 0.243 units with the assumption that the service quality variable is fixed.

c. Service quality variable (X2) is b2 $=0.297$ and is positive meaning that each increase in service quality variable by 1 unit, so the value of the purchase decision will increase by 0.297 units with 
assumption that variable customer satisfaction is fixed.

Table 2 Coefficient of Determination

\begin{tabular}{|l|l|r|r|rr|}
\hline Model & R & R Square & Adjusted R Square & Std. Error of the Estimate & 7.809 \\
\hline 1 & $.413^{\mathrm{a}}$ & .170 & .154 & & \multicolumn{1}{c|}{. } \\
\hline
\end{tabular}

a. (Constant), Service_Quality, Customer_Satisfaction

b. Purchase Decisions

Based on Table 2 above, the coefficient of determination (adjusted $\mathrm{R}^{2}$ ) is 0.154 . This shows that $15.4 \%$ of the variation in Purchase Decision variable $(\mathrm{Y})$ can be explained by variations in customer satisfaction variable $\left(\mathrm{X}_{1}\right)$ and service quality variable $\left(\mathrm{X}_{2}\right)$, while the remaining of $84.6 \%$ are variations of other variables not explained in this study, such as prices, distribution channels, product quality and so on.

Table 3 The Result of F Statistical test

\begin{tabular}{|rl|l|r|r|r|c|}
\hline Model & & Sum of Squares & df & Mean Square & F & Sig. \\
\hline \multirow{2}{*}{1} & Regression & 1238.856036 .987 & 2 & 619.42860 .980 & 10.158 & $.000^{\mathrm{b}}$ \\
& Residual & & 99 & & & \\
& Total & 7275.843 & 101 & & & \\
\hline
\end{tabular}

a. Purchase Decisions

b. (Constant), Service_Quality, Customer_Satisfaction

From Table 3 above, the value of $F_{\text {count }}$ is $10,158>F_{\text {table }}$ by 3.09 with Sig. $0.000<0.05$. This shows that $\mathrm{H}_{0}$ is rejected and $\mathrm{H}_{1}$ is accepted. This means that customer satisfaction variable (X1) and service quality variable (X2) simultaneously have a positive and significant influence on purchase decisions (Y) at PT. Era Graha Perkasa Medan

Table 4

The Result of Statistical test

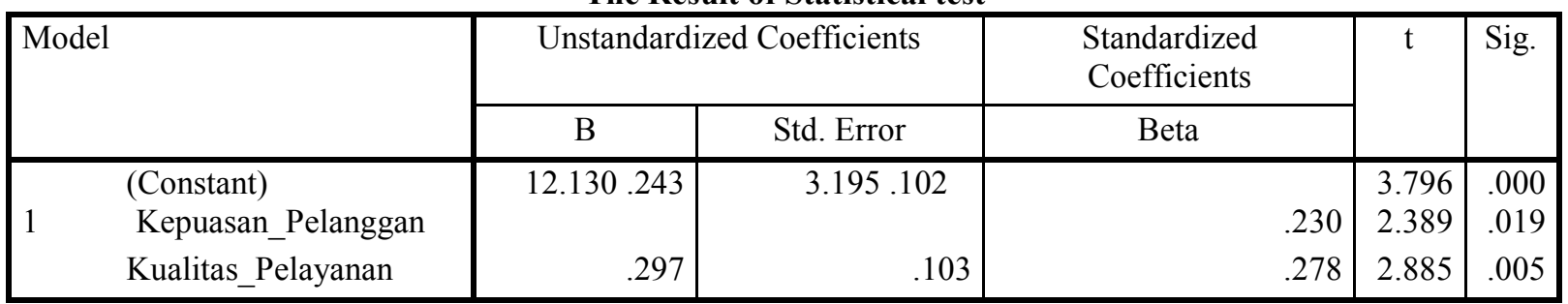

a. Purchase Decisions

The result of the partial statistical test is as follows:

1. Customer satisfaction variable has a $t_{\text {count }}$ value of 2,389 and a $t_{\text {table }}$ value of 1,984 , then the value of $\mathrm{t}_{\text {count }}>\mathrm{t}_{\text {table }}(2.389>1.984)$ with a significant value of $0.019<0.05$, so that the research result rejects $\mathrm{H} 0$ and accepts $\mathrm{h} 1$. Thus it can be concluded that the variable of customer satisfaction $\left(\mathrm{X}_{1}\right)$ partially has a positive and significant influence on purchase decisions (Y) at PT Era Graha Perkasa Medan

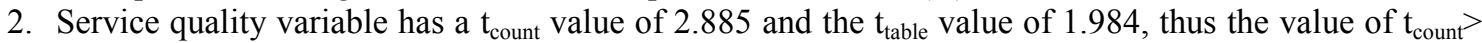
$\mathrm{t}_{\text {table }}(2,885>1,984)$ with a significant value of $0.005<0.05$, so the results of the study reject $\mathrm{H}_{0}$ and accept $\mathrm{H}_{1}$. Hence it can be concluded that service quality variable $\left(\mathrm{X}_{2}\right)$ partially has a positive and significant influence on purchase decision (Y) at PT Era Graha Perkasa Medan.

Those two variables above show that the service quality variable is more dominant than the customer satisfaction variable which can be seen from the regression coefficients of service quality greater than that of customer satisfaction $(0.297>0.243)$.

The Influence of Customer Satisfaction $\left(\mathrm{X}_{1}\right)$ on Purchase Decision (Y)

The hypothesis of this study states that customer satisfaction partially influences purchase decisions at PT. Era Graha Perkasa Medan Based on these results, the hypothesis of this study is correct.

These research results prove that customer satisfaction partially has a positive and significant effect on purchase decisions at PT. Era Graha Perkasa Medan by having a $t_{\text {count }}$ value of 2.389 and $t_{\text {table }}$ value of 1.984 so the value of $\mathrm{t}_{\text {count }}>\mathrm{t}_{\text {table }}(2.389>1.984)$ with a significant value of $0.019<0.05$.

According to Abdullah and Tantri (2015: 223) these research results are in accordance with experts; opinion that consumers set a value expectation and act on it. Then, they will find out whether an offer really fulfills its expected value, which affects their satisfaction and the possibility of repurchase.

The finidngs are in line with the research conducted by Muiszudin (2015) entitled "The Effects of Consumer Satisfaction on Purchase Decisions of Flight Ticket at PT Arwana Internusa Tour Pontianak" which states that customer satisfaction has an effect on purchase decisions.

Based on the explanation above, it can be concluded that customer satisfaction has an effect on purchase 
decisions. The better the customer satisfaction, the better the purchase decisions. Therefore, companies must pay more attention to customer satisfaction so that maximum purchase decisions are more easily achieved.

The Influence of Service $\left(\mathrm{X}_{2}\right)$ on Purchase Decisions $(\mathrm{Y})$

The hypothesis of this study states that service quality partially influences purchase decisions at PT. Era Graha Perkasa Medan. Based on these results, the hypothesis of this study proved correct.

The results of the study prove that service quality partially has a positive and significant influence on purchase decisions at PT Era Graha Perkasa Medan with $t_{\text {count }}$ value of 2.885 and $t_{\text {table }}$ of 1.984 so the value of $\mathrm{t}_{\text {count }}>\mathrm{t}_{\text {table }}(2.885>1.984)$ with a significance value of $0.005<0.005$.

According to Sachaeri (2012: 5), this result is in accordance with experts' opinion that customers will feel satisfaction and pleasure because of the services quality provided. They will come back to visit and buy"

This result is in line with the research carried out by David (2013) entitled "Promotion and Quality of Service Affect on

Consumer Decisions to Use Financing Services at PT. Bess Finance Manado "which states that product quality influences purchasing decisions.

Based on the explanation above, it can be concluded that service quality is important in supporting purchase decisions. The better the quality of service, the better the purchase decision will be. Therefore, companies must pay more attention to the service quality.

\section{CONCLUSION AND SUGGESTION}

Based on the reseach results and discussion, it can be concluded that:

1. Customer satisfaction variable (X1) partially has a positive and significant influence on purchase decisions (Y) at PT Era Graha Perkasa

Medan by 2.389 and the $t_{\text {table }}$ value is 1.984 , thus the value of $t_{\text {count }}>t_{\text {table }}(2,389>1,984)$ with a significant value of $0.019<0.05$.

2. Service quality variable (X2) partially has a positive and significant influence on purchase decisions (Y) at PT Era Graha Perkasa

Medan by 2.885 and the $t_{\text {table }}$ value is 1.984 , thus the $t_{\text {count }}>t_{\text {table }}(2.885>1.984)$ with a significant value of $0.005<0.05$.

3. Customer satisfaction variables $\left(X_{1}\right)$ and service quality variables $\left(X_{2}\right)$ simultaneously have a positive and significant influence on purchase decisions (Y) at PT. Era Graha Perkasa Medan with the coefficient of determination (Adjusted $\mathrm{R}^{2}$ ) of $15.4 \%$.

Suggestion

Based on the results of this study, the researchers give suggestions or input as follows:

1. For PT Era Graha Perkasa Medan

For companies, it is better to pay more attention to customer satisfaction and service quality because high customer satisfaction affects purchase decisions. As with the quality of service, the better the quality of service, the easier the way to improve purchase decisions.

2. For Universitas Prima Indonesia

For Universitas Prima Indonesia, it is better to provide more choice of variables to study so that it will further broaden the research horizons.

3. For Further Study

The next researchers are better to use other variables such as price, distribution channel, and product quality so that more information about matters that influence purchase decisions will be obtained and become a reference for future researchers who will examine the similar problem.

4. For Researchers

For researchers, it is better to look for more theories that support the results of research on the effect of customer satisfaction and service quality on purchase decisions.

\section{DAFTAR PUSTAKA}

Abdullah, Thamrin dan Francis Tantri. 2014. Manajemen Pemasaran. Ed. 1 Cetakan 4, Jakarta : Rajawali Pers.

Arianty, Nel, Dewi Andriany dan Hanifah Jasin. 2015. Manajemen Pemasaran. Cetakan 1, Medan : Perdana Publishing.

Daud. 2013. Promosi Dan Kualitas Layanan Pengaruhnya Terhadap Keputusan Konsumen Menggunakan Jasa Pembiayaan Pada Pt. Bess Finance Manado. Jurnal EMBA.

Hasan, Ali. 2014. Marketing Dan Kasus-Kasus Pilihan. Cetakan Pertama. Yogyakarta : CAPS.

Herlambang, Susatyo. 2014. Basic Marketing (Dasar-Dasar Pemasaran) : Cara Mudah Memahami Ilmu

Pemasaran. Cetakan 1, Yogyakarta : Gosyen Publishing.

Limakrisna dan Nanda Susilo. 2012. Manajemen Pemasaran. Jakarta: Amitra Wacana Media. 
Marwanto, Aris. 2015. Marketing Sukses. Cetakan 1. Yogyakarta : Kobis.

Meliana, Sulistiono dan Budi Setiawan. 2013. Pengaruh Kualitas Pelayanan dan Kepercayaan Konsumen Terhadap Keputusan Pembelian Studi Kasus Pada Giant Hypermarket. Jurnal Ilmiah Manajemen Kesatuan.

Muiszudin, Ori Sista. 2015. Pengaruh Kepuasan Konsumen Terhadap Keputusan Pembelian Tiket Pesawat Di PT.Arwana Internusa Tour Pontianak. Jurnal Manajemen.

Nitisusastro, Mulyadi. 2013.Perilaku Konsumen Dalam Perspektif Kewirausahaan. Bandung : Alfabeta.

Sangadji, Etta Mamang \& Sopiah. 2013. Perilaku Konsumen : Pendekatan Praktis Disertai : Himpunan Jurnal Penelitian. Ed. 1. Yogyakarta : Andi Offset.

Siregar, Syofian. 2014. Statistik Parametrik Untuk Penelitian Kuantitatif Dilengkapi Dengan Perhitungan Manual dan Aplikassi SPSS Versi 17.

Jakarta : Bumi Aksara.

Soedjas, T. 2014. Layanan Wow Untuk Pelanggan, Cetakan pertama. Jakarta: PT Buku Seru.

Suchaeri, Heri. 2012. Total Customer Percepatan Laba Sepanjang Masa. Solo: PT Tiga Serangkai Pustaka Mandiri.

Sugiyono. 2010. Metode Penelitian Kuantitatif, Kualitatif dan R\&D. Bandung : Alfabeta.

Sunyoto, Danang. 2014. Konsep Dasar Riset Pemasaran \& Perilaku Konsumen. Yogyakarta : CAPS. 2015. Perilaku Konsumen dan Pemasaran : Panduan Riset Sederhana Untuk Mengenali Konsumen. Cetakan 1. Yogyakarta : CAPS.

Suparyanto, RW dan Rosad. 2015. Manajemen Pemasaran : Dilengkapi 45 Judul Penelitian \& Kasus Seharihari di Indonesia. Bogor : In Media.

Supranto, dan Nandan Limakrisna, 2011. Perilaku Konsumen dan Strategi Pemasaran, Edisi Kedua. Jakarta: Mitra Wacana Media.

Tjiptono, Fandy. 2014. Strategi Pemasaran. Yogyakarta: Andi.

Tjiptono, Fandy dan Gregorius Chandra. 2012. Pemasaran Strategik, Edisi-II.

Yogyakarta: C.V. Andi Offset.

Umar, Husein. 2010. Desain Penelitian MSDM dan Perilaku Karyawan.

Jakarta : Raja wali Press 